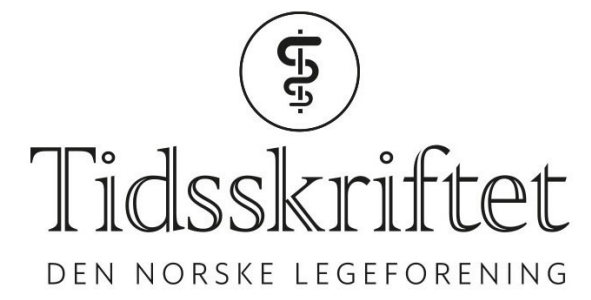

\title{
Bør vi slutte å snakke om emosjonell inkontinens?
}

SPRÅKSPALTEN

\section{TORGEIR BRUUN WYLLER}

E-post: t.b.wyller@medisin.uio.no

Torgeir Bruun Wyller (f. 1960) er spesialist i indremedisin og i geriatri, professor i geriatri ved Universitetet i Oslo og overlege ved Oslo universitetssykehus.

Emosjonell inkontinens er et talende uttrykk som har vært i bruk i mange år. Symptomet kjennetegnes av umotivert gråt eller latter. Dette er relativt vanlig den første tiden etter hjerneslag og forekommer også ved en rekke hjernesykdommer, inkludert demens. Enkelte finner ordet inkontinens støtende brukt i denne sammenhengen. Jeg foreslår at emosjonell labilitet kan brukes i stedet.

Uttrykket emosjonell inkontinens har en lang historie i engelsk. I Oxford English Dictionary er første oppslag fra The Lancet i 1875 (1). Første treff på norsk i det digitale nasjonalbiblioteket (bokhylla.no) er fra 1933 (2). Det står også i moderne medisinske ordbøker fra Samlaget («sviktande evne til å styra kjensleuttrykka sine, eit drag som kan koma etter hjerneslag eller andre hjerneskadar») (3) og Kunnskapsforlaget («manglende evne til å styre følelser») (4).

Uttrykket er på mange måter talende (5). Pasientene har ikke noen egentlig affektiv forstyrrelse, de er bare ekstremt «lettrørte». Små emosjonelle krusninger kommer mye voldsommere til overflaten enn hva som regnes som normalt. Det «renner over», de «lekker» følelser. For det er ikke bare gråt det gjelder, selv om det er vanligst, men også latter som er overdreven ut fra den sosiale konteksten.

I uttalte tilfeller kan tilstanden være sterkt sosialt invalidiserende, selv om pasienten ikke er deprimert. Det er ikke så fristende å gå tilbake til bridgeklubben på eldresenteret hvis man bryter ut i gråt når man får sparesset. I uttalte tilfeller kan selektive serotoninreopptakshemmere hjelpe, selv om pasienten ikke er klinisk deprimert (6).

Inkontinens brukes vanligvis om manglende kontroll på avføring eller urin. Det kommer av latin in- «ikke, u-» og continentia «selvbeherskelse». Enkelte har ansett assosiasjonene til urinog avføringsinkontinens som støtende, og derfor har jeg gått over til å bruke «emosjonell labilitet» (7). Terminologien på feltet er forvirrende og av enkelte beskrevet som et semantisk minefelt. Tallrike termer brukes til å beskrive tilstanden (8): patologisk latter og gråt, emosjonell dyskontroll, eksessiv emosjonalitet, patologisk affekt og pseudobulbær gråt er eksempler (9). Blant forslagene er også emosjonell instabilitet (10), men siden dette også brukes ved diagnosen emosjonell ustabil personlighetsforstyrrelse, tror jeg at emosjonell labilitet vil fungere bedre som avløseruttrykk når vi skal beskrive en tilstand der 
pasientene plages av umotivert gråt eller latter.

LITTERATUR:

1. Emotional incontinence. I: Oxford English Dictionary. http://www.oed.com/view/Entry/61251

(10.12.2017).

2. Dahlstrøm S. Alkoholsløvsinn. I: Kreyberg L, red. Vår helse: populært norsk legeverk. Bd. 2. Oslo: Nasjonalforlaget, 1933: 212.

https://www.nb.no/nbsok/nb/32902f984ac4143b5e5do1f8250667b5?index=1\#213 (10.12.2017).

3. Emosjonell inkontinens. I: Øyri A. Norsk medisinsk ordbok. 9. utg. Oslo: Samlaget, 2011: 284.

4. Emosjonell inkontinens. I: Nylenna M. Medisinsk ordbok. Kunnskapsforlaget.

https://www.ordnett.no/search?languageno\&phraseemosjonell+inkontinens (10.12.2017).

5. Wyller TB, Sveen U. Ikke-språklige kognitive symptomer etter hjerneslag. Tidsskr Nor Lægeforen 2002; 122: 627-30. [PubMed]

6. Andersen G, Vestergaard K, Riis JO. Citalopram for post-stroke pathological crying. Lancet 1993; 342 : 837 - 9. [PubMed][CrossRef]

7. Wyller TB. Geriatri: en medisinsk lærebok. 2. utg. Oslo: Gyldendal akademisk, 2015.

8. Wortzel HS, Oster T], Anderson CA et al. Pathological laughing and crying : epidemiology, pathophysiology and treatment. CNS Drugs 2008; 22: 531 - 45. [PubMed][CrossRef]

9. Lauterbach EC, Cummings JL, Kuppuswamy PS. Toward a more precise, clinically-informed pathophysiology of pathological laughing and crying. Neurosci Biobehav Rev 2013; 37: 1893 - 916. [PubMed][CrossRef]

10. Fure B. Depresjon, angst og andre emosjonelle symptomer ved hjerneslag. Tidsskr Nor Lægeforen 2007; 127: 1387- 9. [PubMed]

Publisert: 8. mai 2018. Tidsskr Nor Legeforen. DOI:10.4045/tidsskr.18.0048

(C) Tidsskrift for Den norske legeforening 2020. Lastet ned fra tidsskriftet.no 